\title{
EFEKTIFITAS PEMASARAN POLITIK (PULL MARKETING) TERHADAP KEMENANGAN ABM-ENNY PADA PEMILIHAN GUBERNUR SULAWESI BARAT TAHUN 2017
}

\author{
Sadar Bahtiar ${ }^{\text {a1 }}$, Rifaid ${ }^{\text {b2 }}$ \\ ${ }^{a}$ Universitas Muhammadiyah Palangka Raya

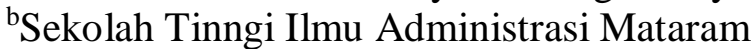 \\ 1 bahtiarsadar1994@gmail.com, ${ }^{2}$ rifaid@stiamataram.ac.id,
}

\section{INFO ARTIKEL}

Riwayat Artikel:

Diterima: 26-07-2020

Disetujui: 21-08-2020

\section{Kata Kunci:}

1. Pemasaran Politik

2. Pull Marketing

3. Pemilihan Gubernur

\author{
Abstract: \\ 1. Political Marketing \\ 2. Pull Marketing \\ 3. Governor Election
}

\begin{abstract}
ABSTRAK
Abstrak: Information Communication Technologi (ICT) merupakan sarana yang sangat berperan atas perubahan kehidupan masyarakat. Kebisaan masyarakat kini bergeser masuk kedalam pemanfaatan TIK, meninggalkan cara lama menuju cara baru. Demokrasi digital adalah salah satu bentuk penggunaan TIK dalam area politik. Demokrasi digital merupakan istilah yang digunakan untuk menggambarkan penggunaan media internet dalam ruang lingkup politik. Pemanfaatan media internet dengan beberapa jenis platform kini menjadi wadah bagi pelaku politik praktis untuk melakukan kampanye politik. Pengunaan media internet dalam ranah politik bukan hanya dilakukan oleh para kontestan politik melainkan juga dilakukan oleh para penyelenggara dan pengwas pemilihan seperti KPU, BAWASLU dan beberapa Lembaga lain dengan peran dan koridor masing-masing. Media internet dengan beberapa jenis platform media sosial adalah wadah dalam menyampaikan pesan politik kepada masyarakat. Penelitian ini menggunankan pendekatan kualitatif yang menghasilkan data derskriptif berupa kata-kata tertulis atau lisan dari orang-orang dan perilaku yang diamati. Tujuan penelitian ini untuk mengetahui efektifitas pemasaran politik (pull marketing) terhadap kemenangan ABM-Enny. Hasil penelitian menunjukkan bahawa pemasaran politik Pull marketing ABM-Enny bersama timnya dalam kemenangan pada pemilihan gubernur Sulawesi Barat tahun 2017 cukup efektif. Hal itu tercapai karena kemampuan aktivitas pemasaran politik yang dilakukan, dengan menggunakan strategi pull marketing yang dikombinasikan dengan strategi pemsaran politik yang lainnya seperti startegi push marketing dengan pass marketing. Yaitu pemanfaatan media sosial dalam mobilisasi massa yang sebelum melakukan kunjungan langsung kelapangan (pull marketing). Pemasaran politik yang dilakukan melalui media sosial juga dimanfaatakna dengan strategi menghadirkan para figur yang dianggap berpengaruh sehingga dapat pula mempengaruhi pilihan masyarakat (pass marketing).
\end{abstract}

Abstract: Information Communication Technology (ICT) is a very important means of changing people's lives. The ability of the community is now shifting into the use of ICT, leaving the old ways towards new ways. Digital democracy is a form of ICT use in the political sphere. Digital democracy is a term used to describe the use of internet media in the political sphere. The use of internet media with several types of platforms has now become a forum for practical political actors to carry out political campaigns. The use of internet media in the political sphere is not only done by political contestants but also by election organizers and monitors such as the KPU, BAWASLU and several other institutions with their respective roles and corridors. Internet media with several types of social media platforms are a means of conveying political messages to the public. This study uses a qualitative approach that produces descriptive data in the form of written or oral words from people and observed behavior. The purpose of this study was to determine the effectiveness of political marketing (pull marketing) to win ABM-Enny. The results showed that ABM-Enny's pull marketing political marketing with his team in the victory in the election of the governor of West Sulawesi in 2017 was quite effective. This was achieved because of the ability of political marketing activities undertaken, using pull marketing strategies combined with other political marketing strategies such as push marketing strategies with pass marketing. Namely the use of social media in mass mobilization which before direct field visits (pull marketing). Political marketing which is carried out through social media is also utilized by the strategy of presenting figures who are considered 


\section{LATAR BELAKANG}

Revolusi industry 4.0 telah membawa masyarakat manusia kezaman modern. Penyesuain gaya hidup disesuaikan dengan perkembngan zaman. Kemajuan zaman dengan revolusi industry 4.0 ini berdampak terhadap beberpa interaksi masyarakat. Dari awalnya setiap aktivitas dilakukan secara konvensional kini beralih kepada cara-cara yang baru. Teknologi informasi (TIK) atau dalam Bahasa internasionalnya dikenal dengan istilah Information Communication Technologi (ICT) merupakan sarana yang sangat berperan atas perubahan kehidupan masyarakat. Masyarakat manusia begitu dimudahkan dalam berbagai urusan dengan memanfaatkan TIK. Kebisaan masyarakat kini bergeser masuk kedalam pemanfaatan TIK, meninggalkan caracara yang konvensional seperti saat membeli makanan yang sebelumnya harus keluar rumah kini bisa dilakan transaksi dengan tetap tinggal dirumah.

Begitu pesatnya penggunaan TIK bahkan menjadi alat untuk menggerakkan segala lini kehidupan baik dari segi Pendidikan, Kesehatan, Ekonomi dan Agama. Tidak tertinggal juga pada bidang Politik. Demokrasi digital adalah salah satu bentuk penggunaan TIK dalam area politik. Demokrasi digital merupakan istilah yang digunakan untuk menggambarkan penggunaan media internet dalam ruang lingkup politik. Melalui jejaring internet, informasi dapat tersebar dengan sangat pesat kepada seluruh lapisan masyarakat baik masyarakat perkotaan maupun pedesaan selama terjangkau oleh jaringan internet, dan tidak dapat dikendalikan oleh siapapun termasuk oleh pemerintah itu sendiri. (Firmanzah, 2018).

Oleh karena itu, pemanfaatan media internet dengan beberapa jenis platform kini menjadi wadah bagi pelaku politik praktis untuk melakukan kampanye politik. Pemanfaatan media internet dalam melakukan pemasaran politik cukup banyak digunakan oleh para kontestan politik. Pengunaan media internet dalam ranah politik bukan hanya dilakukan oleh para kontestan politik melainkan juga dilakukan oleh para penyelenggara dan pengawas pemilihan seperti Komisi Pemilihan Umu (KPU), Badan Pengawas Pemilihan Umum (BAWASLU) dan beberapa Lembaga lain dengan peran dan pada koridornya masing-masing.
Pemanfaatan media internet dengan beberapa jenis platform media sosial dianggap sebagai salah satu wadah dalam menyampaikan pesan politik kepada masyarakat.

Pemanfaatan media siosial dalam aktivitas politik praktis sudah banyak dilakukan, seperti disampaikan sebelumnya bahwa baik dari kontestan itu sendiri maupun oleh penyelenggara atau pengawas pemilihan. Upaya-upaya yang dilakukan merupakan bagian dari Pendidikan politik. Penggunaan media sosial dalam menyampaikan pesan politik juga pernah dipraktekkan dalam lingkungan kampus dalam hal pemilu raya. Diataranya dapat kita lihat pada apa yang sudah diteliti oleh (Riciani, 2016) dalam jurnal Kajian Moral dan Kewarganegaraan dengan judu artikel "Peran Komisi Pemilihan Umum Raya Melalui Media Sosial Dalam Upaya Meningkatkan Partisipasi Politik Mahasiswa Pada Pemilu Raya Prodi PPKN Unesa Periode 20162017" hasil penelitian menunjukkan bahwa Hasil penelitian ini menunjukkan bahwa peran KPUR dalam menjalankan tugasnya dengan memberikan sosialisasi Pemilu Raya meliputi peraturan Pemilu Raya, agenda kegiatan, persyaratan, dan ketentuan serta tata cara dalam memilih. Sosialisasi dilakukan melalui empat media sosial yakni BBM, line, whatsapp dan facebook. Partisipasi politik mahasiswa meliputi partisipasi politik aktif yang dipengaruhi faktor kesadaran politik yang tinggi, sosialisasi melalui media sosial dan ajakan teman. Partisipasi pasif dipengaruhi oleh faktor kesadaran politik yang rendah sedangkan golput dipengaruhi oleh faktor sistem politik dan masyarakatnya tidak sesuai dengan yang diharapkan. Penelitian yang hampir serupa juga dilakukan oleh (Morissan, 2014) dengan judul penelitian Media Sosial Dan Partisipasi Sosial Di Kalangan Generasi Muda. Pada penelitian ini, di paparkan bagaimna generasi mudah sangat aktif dalam penggunaan media sosial. Hal ini mempengaruhi pula tingkat partisipasi politik diantara mereka. Sebagian asumsi mengatakan bahwa generasi muda dianggap apatis terhadap hal-hal yang berbau politik, namun pada penelitian ini memberikan tanggapan bahwa generasi muda tidak demikian melainkan aktif dalam mengemukakan preferensi dan minat mereka terhadap politik bahkan Sebagian dari generasi muda lebih aktif dari pda Sebagian generasi tua. Selain aktif sebagai 
partisipan politik juga aktif memberikan saran agar pandangan mereka dapat didengar oleh para pemangku kepentingan. Penelitian selanjutnya datang dari Universitas Kebangsaan Malaysia yang dilakukan oleh Akmal dan salman (2015). Judul penelitian Partisipasi Politik Belia Secara Online Melalui Ruang Demokrasi Maklumat Media Baru. Hasil pnelitian menunjukkan bahwa melalui media sosial kalangan muda aktif dalam partisipasi politik. Selanjutnya penelitian yang dilakukan oleh (Ardha, 2014) dengan judul penelitian Sosial Media sebagai Kampanye Politik 2014 di Indonesia. Artikel tersebut yang termuat dalam Jurnal Visi Komunikasi ber-kesimpulan bahwa media sosial telah memainkan dan akan terus memainkan peranan penting dalam kontelasi politik di 2014. Dengan pemnfaatan berbagai platform media sosial seperti facebook, twetter, dan Youtube para kandidat politik akan terus berinteraksi dengan pendukung dan akan terus menerima dukungan dalam bentuk sumbangan maupun relawan. Penelitian yang hampir serupa juga dilakukan oleh (Alami, 2013) dengan judul penelitian Menakar Kekuatan Media Sosial Menjelang Pemilu 2014. Pada penelitian tersebut, memberikan kesimpulan bahwa kemajuan teknologi dan informasi menutntut para partai politik untuk mendayagunakan kekuatan media sosial dalam aktivitas politiknya. Hal tesebut penting untuk melakukan interasksi politik dengan msyarakat. Dalam penelitian tersebut disebutkan bahwa tahun-tahun mejelang pemulu 2014 media sosial telah menjadi bagaian dari saluran politik yang penting. Dengan media sosial maka dimungkinkan intitusi politik baik parpol dan konstituen atau pemilih dapat saling berinteraksi secara langsung. Bahkan media sosial juga dapat menjadikan komunikasi politik lebih egaliter dan demokratis. Dalam situasi tersebut maka aktivitas politik akan lebih transparan dan masyarakat pun dapat lebih terlibat dalam proses pembuatan kebijakan. Selanjutnya penelitian yang dilakukan oleh (Nurfalah dan Wihayati, 2013) dengan judul penelitian Persepsi Khalayak Dalam Penggunaan Media Jejaring Sosial Untuk Kampanye Politik. Ada tiga poin utama pada penelitian ini yaitu 1. Persepsi masyarakat mengenai penggunaan media jejaring sosial untuk kampanye politik di Kota Cirebon masih dalam batas wajar untuk digunakan sebagai media kampanye politik jika tidak membohongi masyarakat tidak melanggar hukum dan dinilai efektif; 2. Hambatan penggunaan media jejaring sosial untuk kampanye politik bahwa tidak semua masyarakat memakai media jejaring sosial, Ketika ada pro dan kontra di media jejaring sosial terjadi saling mengintimidasi, bahkan ada yang menghacker, membajak, seolah-olah sebagai calon kandidat dan menjelek-jelekkann kandidat lain; 3. Penunjang penggunaan media jejaring sosial untuk kampanye politik, yaitu akan banyak follower, respek kepada kandidat, dapat mengumpulkan dana, dapat melakukan pengabdian kepada masyarakat, bahkan foto pribadi dan kegiatan harian dapat di update, status membangin yang direalisasikan didunia nyata, dan komentar-komentar membangun. Selanjutnya penelitian yang dilakukan oleh (Ratnamulyani dan Maksudi, 2018) dengan judul penelitian peran media sosial dalam peningkatan partisipasi pemilih pemula dikalangan pelajar di kabupaten Bogor. Hasil penelitian menunjukkan bahwa pengguna media sosial semakin massif khususnya dikalangan para pemilih pemula yakni kalangan pelajar di Kabupaten Bogor untuk mengakses informasi terkait pemilu. Diantara flatform media sosial yang digunakan ialah Twetteer sebanyak 35\%, Facebook sebanyak 28\% dan Instagram sebanyak $28 \%$.

Dari beberapa tinjauan Pustaka yang telah dipaparkan diatas, secara garis besar semuanya membahas mengenai pemanfaatan media elektronik dalam aktivitas politik. Sehingga hanya bisa dilihat bagaimana media internet/media sosial itu digunakan oleh para aktor politik maupun dari penyelenggara pemilu itu sendiri. Oleh karena itu, penelitian ini akan lebih fokus terhadap penggunaan media sosial dalam kampanye politik dengan menitik beratkan pembahasan pada startegi Pull marketing dalam teori marketing politik.

\section{TINJAUAN PUSTAKA}

\section{Strategi Pemasaran Politik}

\section{Push Marketing}

Push marketing pada dasarnya adalah usaha agar produk politik dapat menyentuh para pemilih secara langsung atau dengan cara yang lebih personal (constomized), dalam hal ini kontak langsung dan personal mempunyai beberapa kelebihan, yaitu : Pertama, mengarahkan para pemilih menuju suatu tingkat kognitif yang berbeda dibandingkan dengan bentuk kampanye lainnya. Politisi yang berbicara langsung akan memberikan efek yang berbeda dibandingkan dengan melalui iklan. Kedua, kontak langsung memungkinkan pembicaraan dua arah, melakukan persuasi dengan pendekatan verbal dan non verbal seperti tampilan, ekpresi wajah, bahasa tubuh dan isyarat-isyarat fisik lainnya. Ketiga, menghumaniskan kandidat dan keempat, meningkatkan antusiasme massa dan menarik perhatian media massa. Selain itu push political 
marketing adalah bentuk penyampaian produk politik kepada para pemilih menggunakan saluran non-media massa, (Nursal, 2004).

Push marketing dapat dilakukan dengan turun ke lapangan untuk dapat langsung berinteraksi dengan konstituen, seperti dalam kegiatan keagamaan, maupun, undangan-undangan, melakukan kunjungan-kunjungan atau agenda yang tidak direncanakan (Pangemanan, 2013). Selain itu hasil temuan yang dilakukan oleh (Agama, 2015) juga menemukan bahwa pendekatan di dalam pemasaran politik dapat dilakukan dengan menggunakan pendekatan push marketing berupa penciptaan jaringan pendukung yang terfokus dan bergerak pada wilayah tertentu yang dapat memfasilitasi interaksi bersama pemilih.

Secara umum, sentuhan langsung kepada para pemilih dapat dilakukan dengan mengadakan eventevent khusus seperti rapat umum, pawai, kontes, seminar, konfrensi dan sebagainya. Disamping event-event besar, sentuhan langsung kepada para pemilih juga dapat dilakukan melalui beberapa kegiatan berskala kecil seperti pembicaraan personal, lobi politik, persentasi terbatas, pertemuan terbatas dan seminar.

\section{Pass Marketing}

Menurut (Nursal, 2004) dalam pemasaran politik, pass marketing merupakan pihak-pihak, baik perorangan maupun kelompok yang berpengaruh besar terhadap para pemilih. Pengaruh (influencer) dikelompokan kedalam dua jenis yakni influencer aktif dan influencer pasif. Influencer aktif adalah perorangan atau kelompok yang melakukan kegiatan secara aktif untuk mempengaruhi para pemilih. mereka adalah aktivis isu-isu tertentu atau kelompok dengan kepentingan tertentu yang melakukan aktivitas nyata untuk mempengaruhi para pemilih. Adakalanya pesan-pesan tersebut disampaikan secara halus adakalanya juga secara terang-terangan untuk mengarahkan pemilih agar memilih atau tidak memilih kontestan tertentu. Sebagian melakukan kegiatan dengan organisasi yang rapih dan sebagian lainya secara informal. Sedangkan influencer pasif adalah individu atau kelompok yang tidak mempengaruhi para pemilih secara aktif tapi menjadi rujukan para pemilih. mereka inilah para selebriti, tokoh-tokoh, organisasi sosial, organisasi massa yang menjadi rujukan atau panutan masyarakat. Suara mereka didengar dan sepak terjang mereka memiliki makna politis tertentu bagi para pengikutnya. Mereka memiliki pengikut dengan berbagai macam kategori seperti anggota, pendukung, dan penggemar. Para pengikut tersebut dekat dengan para influencer, baik dalam pengertian fisik maupun emosional.

Pass marketing dapat terlaksana dengan efektif, hal ini dilihat dari mesin partai. Penggunaan organisasi-organisasi sayap partai menarik organisasi-organisasi keagamaan, adat, budaya dan figur-figur yang dianggap berpengaruh dalam organisasi-organisasi tersebut, seperti tokoh-tokoh agama, tokoh masyarkat dan tokoh pemuda yang memiliki basis massa untuk menunjang perolehan suara pasangan tersebut (Pangemanan, 2013). Strategi Pass marketing diterapkan dengan melakukan rekrutmen tokoh lokal dan memanfaatkan tim untuk memberikan pengaruh politik kepada pemilih (Agama, 2015).

\section{Pull Marketing}

Pull political marketing adalah strategi penyampaian pesan yang dilakukan dengan menggunakan media massa baik eletronik maupun media cetak, luar ruang, penggunaan internet dan lain-lain. Pendekatan pull marketing terdiri dari dua cara penggunaan media, yaitu dengan membayar (paid media) dan tanpa membayar (free media) (Nursal, 2004).

Dalam penyampaian produk politik melalui media tanpa pembayaran berkaitan dengan kebutuhan media massa dengan berita. Keuntungan pemberitaan ini adalah tingginya kredibilitas informasi, sedangkan kelemahannya, kontestan politik tidak dapat mengendalikan isi berita yang akan dimuat dan dapat memastikan pemuatannya. Dalam beberapa negara termasuk Indonesia media luar ruangan tidak dipungut biaya sehigga kontestan politik dengan ketentuan waktu dan tempat yang diatur oleh peraturan kampanye bebas dalam memasang poster, leaflet, bendera, spanduk, billboard dan bahkan membuat posko. Sedangkan paid media lazim digunakan unutk memasang iklan seperti televisi, radio, media cetak, website dan media luar ruangan. (Nursal, 2004). Hasil penelitian 
yang dilakukan oleh (Pangemanan, 2013) menemukan bahwa pull marketing dapat dilakukan dengan penggunaan media dalam memasarkan kinerja dan prestasi dari keduanya yang dibungkus melalui media masa. Lewat sarana inilah figur ditonjolkan untuk menarik simpati dari konstituen. Selain itu penelitian juga dilakukan oleh (Agama, 2015) menemukan bahwa pull marketing dapat berupa penggunaan media luar ruangan (spanduk, pamplet, koran stiker serta melalui iklan).

\section{Demokrasi Digital (Digital Democracy)}

Demokrasi digital pada dasarnya merupakan aktivitas politik dengan menggunakan saluran digital, terutama sebagai bentuk partisipasi politik atau penggalangan dukungan publik (Wilhelm, 2003). Dimana dalam arti ini partisipasi publik dimanifestasikan melalui media teknologi, contohnya internet dengan beberapa platform media social seperti Facebook, Instagram, Youtube, Twetteer dan beberapa jenis media sosial yang lainnya.. Melalui demokrasi digital warga negara mendapat jaminan dalam kebebasan berbicara serta menyampaikan aspirasi politiknya pada publik melalui media internet bahkan dalam menyampaiakn gagasan yang paling jenaka sekalipun. Lewat demokrasi digital ini informasi atau kajian politik dapat di produksi secara bebas, dapat disebarkan ke ruang publik, dan dapat sepenuhnya dimanifestasikan secara bebas lewat surat elektronik, media sosial bahkan website.

\section{METODE PENELITIAN}

Artikel ini berangkat dari hasil penelitian yang menggunakan pendekatan penelitian kualitatif. Pendekatan kualitatif menghasilkan data derskriptif berupa kata-kata tertulis atau lisan dari orang-orang dan perilaku yang diamati (Moleong, 2007). Metode kualitatif merupakan prosedur menelitian yang menghasilkan data deskriptif berupa kata-kata tertulis maupun lisan dari orang-orang dan perilaku yang dapat diamati. Data-data yang dipergunakan dalam penelitian ini didapatkan dari kandidat dari Klan Masdar yaitu Ali Baal Masdar/ABM (Gubernur Sulawesi Barat), KPUD Kabupaten Polewali Mandar serta salah seorang dari partai politik pengusung Ali Baal Masdar pađ̧a pemilihan gubernur Sulawesi Barat 2017. Wawancara dilakukan kepada kandidat dari Klan Masdar yaitu Ali Baal Masdar sebagai perwakilan klan dalam kotestasi pemilihan gubernur, masing-masing salah seorang pengurus partai pengusung dan tim relawan/ketua tim koalisi. Studi dokumentasi dilakukan mengenai profil kandidat Klan Masdar dan dokumen perolehan suara.

\section{PEMBAHASAN}

Pemasaran politik mutlak dilakukan menjelang kontestasi politik. Dalam setiap kontestasi politik di Indonesia, penggunaan Teknik pemasaran politik sudah banyak mengantarkan kontestan dalam memeperoleh kemenangan pada kontestan yang diikuti. Baik pada pemilihan kepala daerah, pemilihan legislatif daerah baik kabupaten maupun provinsi. Bahkan pemasaran politik juga dilakaukan pada kontestasi pemilihann presiden dan pemilihan DPR pusat.

Pemasaran politik banyak diartikan oleh beberapa orang ahli, diantaranya adalah Haroen (2014), memberikan pengertian bahwa pemasaran politik merupakan penerapan konsep dan metode marketing didalam dunia politik. Marketing diperlukan dalam memperebutkan pasar dalam pengertian dunia politik pasar diartikan sebagai para calon pemilih. O'Shaunghnessy dalam Firmanzah (2018), mengemukakan bahwa pada pengertiannya, pemasaran politik bukanlah sebuah konsep menjual partai politik ataupu kontestan politik. Namun sebuah konsep yang menawarkan bagaimna partai politik atau para kontestan politik dapat membuat program yang berhubungan dengan permasalahan aktual. Ada beberapa strategi pemasaran politik yang dilakukan oleh para kontestan dalam setiap kontestasi politik seperti strategi Push marketing, Pass marketing dan Pull marketing. Ada juga bentuk lain seperti strategi segmentasi, targeting dan posisitioning. Lebih dalam tentang teori marketing yang diterapkan dalam strategi pemasaran politik seperti dikenal dengan istilah 4P (Firmanzah, 2018) yaitu:

1. Produk (product) berarti partai, kandidat dan gagasan-gagasan partai yang akan disampaikan konstituen.produk ini berisi konsep, identitas ideologi. Baik dimasa lalu maupun sekarang yang berkontribusi dalam pembentukan sebuah produk politik.

2. Promosi (promotion) adalah upaya periklanan, kehumasan dan promosi untuk sebuah partai yang di mix sedemikian rupa sesuai dengan kebutuhan masyarakat. Dalam hal ini, pemilihan media perlu dipertimbangkan.

Harga (price), mencakup banyak hal, mulai ekonomi, psikologis, sampai citra nasional. Harga ekonomi mencakup semua biaya yang dikeluarkan kandidat atau partai selama periode kampanye. Harga psikologis mengacu pada harga persepsi psikologis misalnya, pemilih merasa nyaman, 
dengan latar belakang etnis, agama, pendidikan dan lain-lain . Sedangkan harga citra nasional berkaitan dengan apakah pemilih merasa kandidat tersebut dapat memberikan citra positif dan dapat menjadi kebanggaan negara.

4. Penempatan (place), berkaitan erat dengan cara hadir atau distribusi kandidat atau sebuah partai dan kemampuannya dalam berkomunikasi dengan para pemilih. Ini berati kandidat atau sebuah partai harus dapat memetakan struktur serta karakteristik masyarakat baik itu geografis maupun demografis.

Pemasaran politik memang sebuah persoalan urgen, dimana melalui strategi tersebut kontestan politik dapat memenangkan kontestasi. Berbagai strategi diupayakan termasuk pemanfaatan media elektronik untuk meraih dukungan sebanyak banyak-banyaknya. Selanjutnya akan kita uraikan bagaimana pemnafaatan media internet yang dilakukan oleh ABM-Enny pada kampanye politik pemilihan gubernur Sulawesi Barat tahun 2017.

\section{Strategi Pull marketing Pemasaran Politik ABM- Enny}

Startegi Pull marketing adalah sebuah strategi dalam pemasaran politik. Yaitu sebuah strategi pemanfaatan media dalam melakukan aktivitas kampanye politik. Pemanfaatan media yang dimaksud dalam pull marketing yaitu segala bentuk media yang dapat mengekspos calon kandidat kepada masyarakat sebagai calon pemilih, baik dari media cetak, media elektronik maupun media sosial atau digital. Seiring dengan perkembngan teknologi informasi, maka kehadiran media digital sudah masuk kedalam sendi-sendi kehidupan masyarakat sehingga setiap saat masyarakat dapat mengonsumsi berbagai pemberitaan melalui jejaring internbet pada ponsel mereka masing-masing. Hal tersebutlah yang dimanfaatkan oleh para kontestan untuk pemasaran politik mereka, (Nursal, 2004).

Pemanfaatan media sosial juga dilakukan oleh tim ABM-Enny pada pemilihan gubernur Sulawesi Barat tahun 2017. Tim membentuk strategi pemasaran melalui media sosial dengan berbagai platform media sosial yan dianggap populer dikalangan masyarakat. Selain tim, para pendukung ABM-Enny juga senantiasa melakukan pemasaran politik pada akun mereka masing-masing.
Tabel. 1

\section{Dukungan ABM-Enny di Media Sosial}

\begin{tabular}{|l|l|l|l|}
\hline No & Nama Akun & Platform & Keterangan \\
\hline 1 & $\begin{array}{l}\text { Barisan Muda } \\
\text { ABM-Enny }\end{array}$ & Facebook & $\begin{array}{l}3.869 \\
\text { pengikut }\end{array}$ \\
\hline 2 & $\begin{array}{l}\text { ABM Keris } \\
\text { Muda } \\
\text { Mandar }\end{array}$ & Facebook & 141 anggota \\
\hline 3 & $\begin{array}{l}\text { Akar Rumput } \\
\text { ABM-Enny }\end{array}$ & Instagram & 547 pengikut \\
\hline 4 & Jamar JB & Facebook & 4.982 teman \\
\hline
\end{tabular}

Sumber: Diolah oleh penulis

Pada tabel diatas dapat kita lihat beberapa platform media dan akun yang digunakan dalam melakukan pemasaran politik melalui media sosial. Dari tabel tersebut, platform facebook terlihat lebih banyak, sesuai dengan perkembangan di masyarakat bahwa facebook memang jenis media sosial yang lebih favorit. Pada akun media sosial diatas rata-rata pengikut lebih dari seratus bahkan ada yang jumlahnya ribuan, meskipun tidak dipungkiri bahwa tentu tidak semuanya memberikan dukungan yang sama namun pemasaran politik yang dilakukan pada media sosial dengan jumlah pengikut yang banyak tentu memberikan dampak yang baik.

\section{Strategi Pemasaran Politik Push marketing ABM- Enny dalam Pull marketing}

Push marketing pada dasarnya adalah usaha agar produk politik dapat menyentuh para pemilih secara langsung atau dengan cara yang lebih personal (constomized), dalam hal ini kontak langsung dan personal mempunyai beberapa kelebihan, yaitu : Pertama, mengarahkan para pemilih menuju suatu tingkat kognitif yang berbeda dibandingkan dengan bentuk kampanye lainnya. Politisi yang berbicara langsung akan memberikan efek yang berbeda dibandingkan dengan melalui iklan. Kedua, kontak langsung memungkinkan pembicaraan dua arah, melakukan persuasi dengan pendekatan verbal dan non verbal seperti tampilan, ekpresi wajah, bahasa tubuh dan isyarat-isyarat fisik lainnya. Ketiga, menghumaniskan kandidat dan keempat, meningkatkan antusiasme massa dan menarik perhatian media massa. Selain itu push political marketing adalah bentuk penyampaian produk politik kepada para pemilih menggunakan saluran nonmedia massa, (Nursal, 2004). Kendatipun demikian, bahwa dalam melakukan mobilisasi massa tim ABMEnny lebih dahulu menggunakan strategi pull marketing yaitu pendekatan kepada calon pemilih melalui media, dalam hal ini yaitu media sosial dengan beberapa jenis platform. Ada bentuk pengkolaborasian antara strategi pull marketing dengan strategi push marketing. 
Kemampuan strategi pull marketing ABM-Enny dan timnya dalam melakukan pemasaran politik melalui media sosial membuat ABM-Enny dapat memperoleh kemenangan pada pemilihan gubernur Sulawesi Barat tahun 2017.

Tabel. 2

Perolehan suara ABM-Enny pada pemilihan Gubernur Sulawesi Barat tahun 2017

\begin{tabular}{|c|c|c|c|c|}
\hline No & $\begin{array}{l}\text { Pasangan } \\
\text { Calon }\end{array}$ & Kabupaten & $\begin{array}{c}\text { Perolehan } \\
\text { Suara }\end{array}$ & $\begin{array}{c}\text { Total } \\
\text { Peroleha } \\
\text { n Suara }\end{array}$ \\
\hline \multirow{6}{*}{1} & \multirow{6}{*}{$\begin{array}{l}\text { Suhardi } \\
\text { Duka - } \\
\text { Kalma Katta }\end{array}$} & $\begin{array}{l}\text { Kabupaten } \\
\text { Mamasa }\end{array}$ & $\begin{array}{l}43.951 \\
\text { suara }\end{array}$ & \multirow{6}{*}{$\begin{array}{c}240.010 \\
\text { suara } \\
(38.01 \%)\end{array}$} \\
\hline & & $\begin{array}{l}\text { Kabupaten } \\
\text { Polewali } \\
\text { Mandar }\end{array}$ & $\begin{array}{l}38.331 \\
\text { suara }\end{array}$ & \\
\hline & & $\begin{array}{l}\text { Kabupaten } \\
\text { Majene }\end{array}$ & $\begin{array}{l}42.854 \\
\text { suara }\end{array}$ & \\
\hline & & $\begin{array}{l}\text { Kabupaten } \\
\text { Mamuju }\end{array}$ & $\begin{array}{l}66.909 \\
\text { suara }\end{array}$ & \\
\hline & & $\begin{array}{l}\text { Kabupaten } \\
\text { Mamuju Ten } \\
\text { gah }\end{array}$ & $\begin{array}{l}31.735 \\
\text { suara }\end{array}$ & \\
\hline & & $\begin{array}{l}\text { Kabupaten } \\
\text { Mamuju Uta } \\
\text { ra }\end{array}$ & $\begin{array}{l}16.230 \\
\text { suara }\end{array}$ & \\
\hline \multirow{6}{*}{2} & \multirow{6}{*}{$\begin{array}{l}\text { Salim S. } \\
\text { Mengga - } \\
\text { Hasanuddin } \\
\text { Mas'ud }\end{array}$} & $\begin{array}{l}\text { Kabupaten } \\
\text { Mamasa }\end{array}$ & $\begin{array}{l}8.767 \\
\text { suara }\end{array}$ & \multirow{6}{*}{$\begin{array}{c}146.774 \\
\text { suara } \\
(23.24 \%) .\end{array}$} \\
\hline & & $\begin{array}{l}\text { Kabupaten } \\
\text { Polewali } \\
\text { Mandar }\end{array}$ & $\begin{array}{l}86.608 \\
\text { suara }\end{array}$ & \\
\hline & & $\begin{array}{l}\text { Kabupaten } \\
\text { Majene }\end{array}$ & $\begin{array}{l}21.375 \\
\text { suara }\end{array}$ & \\
\hline & & $\begin{array}{l}\text { Kabupaten } \\
\text { Mamuju }\end{array}$ & $\begin{array}{l}10.130 \\
\text { suara }\end{array}$ & \\
\hline & & $\begin{array}{l}\text { Kabupaten } \\
\text { Mamuju Ten } \\
\text { gah }\end{array}$ & $\begin{array}{l}5.891 \\
\text { suara }\end{array}$ & \\
\hline & & $\begin{array}{l}\text { Kabupaten } \\
\text { Mamuju Uta } \\
\text { ra }\end{array}$ & $\begin{array}{l}14.003 \\
\text { suara }\end{array}$ & \\
\hline \multirow{6}{*}{3} & \multirow{6}{*}{$\begin{array}{l}\text { Ali Baal } \\
\text { Masdar - } \\
\text { Enny } \\
\text { Angraeni } \\
\text { Anwar }\end{array}$} & $\begin{array}{l}\text { Kabupaten } \\
\text { Mamasa }\end{array}$ & $\begin{array}{l}22.769 \\
\text { suara }\end{array}$ & \multirow{6}{*}{$\begin{array}{c}244.763 \\
\text { suara } \\
(38.75 \%)\end{array}$} \\
\hline & & $\begin{array}{l}\text { Kabupaten } \\
\text { Polewali } \\
\text { Mandar }\end{array}$ & $\begin{array}{l}\text { 104.230 } \\
\text { suara }\end{array}$ & \\
\hline & & $\begin{array}{l}\text { Kabupaten } \\
\text { Majene }\end{array}$ & $\begin{array}{l}26.651 \\
\text { suara }\end{array}$ & \\
\hline & & $\begin{array}{l}\text { Kabupaten } \\
\text { Mamuju }\end{array}$ & $\begin{array}{l}46.043 \\
\text { suara }\end{array}$ & \\
\hline & & $\begin{array}{l}\text { Kabupaten } \\
\text { Mamuju Ten } \\
\text { gah }\end{array}$ & $\begin{array}{l}15.549 \\
\text { suara }\end{array}$ & \\
\hline & & $\begin{array}{l}\text { Kabupaten } \\
\text { Mamuju Uta } \\
\text { ra }\end{array}$ & $\begin{array}{l}29.521 \\
\text { suara }\end{array}$ & \\
\hline \multicolumn{4}{|c|}{ Jumlah suara sah } & $\begin{array}{l}631.547 \\
(100 \%)\end{array}$ \\
\hline
\end{tabular}

Sumber: KPUD Kabupaten Polewali

Mandar/Tribun Sulawesi Barat
Tabel diatas menunjukkan bahwa perolehan suara ABM berdasarkan kabupaten meski hanya menang pada dua kabupaten yaitu Kabupaten Polewali Mandar dan Kabupaten Mamuju Utara, namun kemenangan telak ABM di Kabupaten Polewali Mandar merupakan kekuatan utama sebab merupakan wilayah dengan basis massa terbanyak. Sebagai basis massa terbanyak, hampir setiap konsentrasi kampanye politik dipusatkan pada Kabupaten Polewali Mandar. Kekuatan dukungan partai politik di Kabupaten Polewali Mandar juga terbilang kuat, hal ini dapat kita lihat pada jumlah kursi di DPRD Kabupaten Polewali Mandar dari partai koalisi ABMEnny.

Tabel. 3

Jumlah kursi dan dukungan partai politik ABM pada pemilihan gubernur Sulawesi Barat tahun 2017

\begin{tabular}{|c|l|c|r|}
\hline No & $\begin{array}{c}\text { Partai } \\
\text { Politik }\end{array}$ & $\begin{array}{c}\text { Jumlah } \\
\text { Kursi }\end{array}$ & Persentase (\%) \\
\hline 1 & Nasdem & 2 & $4.4 \%$ \\
\hline 2 & PKB & 5 & $11.1 \%$ \\
\hline 3 & PDIP & 5 & $11.1 \%$ \\
\hline 4 & Gerindra & 3 & $6.7 \%$ \\
\hline 5 & PAN & 5 & $11.1 \%$ \\
\hline 6 & PPP & 5 & $11.1 \%$ \\
\hline 7 & PKPI & 1 & $2.3 \%$ \\
\hline \multicolumn{2}{|r|}{ Jumlah } & $\mathbf{2 6}$ & $\mathbf{5 7 . 8 \%}$ \\
\hline
\end{tabular}

Sumber: KPUD Kab. Polman

Berdasarkan tabel diatas dapat kita cermati bahwa dukungan partai politik dan jumlah kursi pada koalisi ABM di Kabupaten Polewali Mandar cukup besar, sehingga di kabupaten ini ABM mengugguli suara pada perolehan suara pemilihan gubernur Sulawesi Barat tahun 2017.

\section{Strategi Pemasaran Politik Pass marketing ABM-Enny dalam Pull marketing}

Menurut (Nursal, 2004) dalam pemasaran politik, pass marketing merupakan pihak-pihak, baik perorangan maupun kelompok yang berpengaruh besar terhadap para pemilih. Pengaruh (influencer) dikelompokkan kedalam dua jenis yakni influencer aktif dan influencer pasif. Influencer aktif adalah perorangan atau kelompok yang melakukan kegiatan secara aktif untuk mempengaruhi para pemilih. mereka adalah aktivis isu-isu tertentu atau kelompok dengan kepentingan tertentu yang melakukan aktivitas nyata untuk mempengaruhi para pemilih. Adakalanya pesanpesan tersebut disampaikan secara halus adakalanya juga secara terang-terangan untuk mengarahkan pemilih agar memilih atau tidak memilih kontestan 
tertentu. Sebagian melakukan kegiatan dengan organisasi yang rapih dan sebagian lainya secara informal. Sedangkan influencer pasif adalah individu atau kelompok yang tidak mempengaruhi para pemilih secara aktif tapi menjadi rujukan para pemilih. mereka inilah para selebriti, tokoh-tokoh, organisasi sosial, organisasi massa yang menjadi rujukan atau panutan masyarakat. Suara mereka didengar dan sepak terjang mereka memiliki makna politis tertentu bagi para pengikutnya. Mereka memiliki pengikut dengan berbagai macam kategori seperti anggota, pendukung, dan penggemar. Para pengikut tersebut dekat dengan para influencer, baik dalam pengertian fisik maupun emosional. Pass marketing dapat terlaksana dengan efektif, hal ini dilihat dari mesin partai. Penggunaan organisasiorganisasi sayap partai menarik organisasiorganisasi keagamaan, adat, budaya dan figur-figur yang dianggap berpengaruh dalam organisasiorganisasi tersebut, seperti tokoh-tokoh agama, tokoh masyarkat dan tokoh pemuda yang memiliki basis massa untuk menunjang perolehan suara pasangan tersebut (Pangeman, 2013). Strategi Pass marketing diterapkan dengan melakukan rekrutmen tokoh lokal dan memanfaatkan tim untuk memberikan pengaruh politik kepada pemilih (Agama, 2015).

Pada pemilihan gubernur Sulawesi Barat tahun 2017. Pasangan ABM-Enny mendapat dukungan dari berbagai tokoh di Sulawesi Barat, dalam pemasaran politik, dukungan tokoh sebagaimana disinggung sebelumnya bahwa masuk dalam kategori pass maeketing yakni seseorang yang dapat memberikan pengaruh (Influencer) sehingga kontestan dapat memperoleh dukungan yang banyak. Adapun tokoh yang dimaksud diantaranya, Syahril Hamdani (tokoh pejuang pembentukan Sulawesi Barat), KH. Syibli Sahabuddin (mantan anggota DPD), H. Umar P (mantan Wakil Bupati Mamuju), dan Amril D. Marrui/bung rio (ketua KNPI Mamuju).

Upaya yang dilakukan dalam strategi pull marketing yaitu menghadirkan para tokoh dalam pemasaran politik yang dilakukan pada jejaring media sosial. Dengan begitu, maka penggabungan antara strategi pass marketing dan pull marketing dapat efektif untuk mempengaruhi calon pemilih.

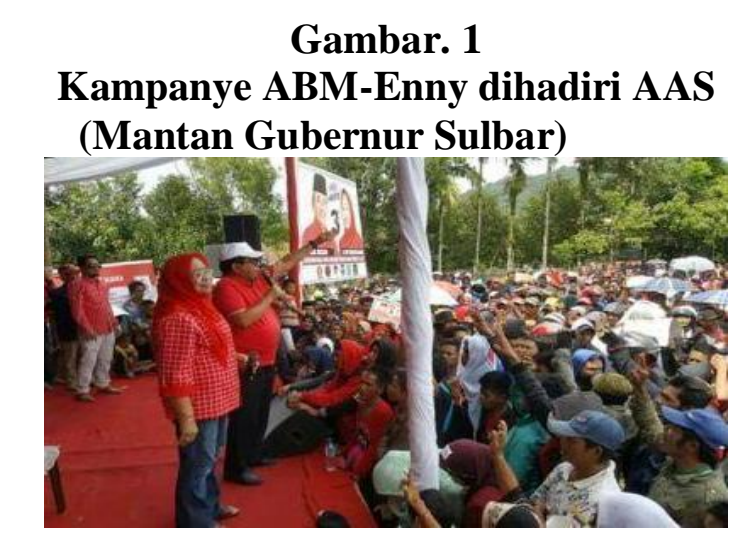

Sumber: Transtipo.com

Kehadiran Enny Anggareni Anwar mempengaruhi kehadiran AAS sebagai tokoh yang cukup memberikan dampak positif pada kemenangan ABM. dalam strategi pemasaran politik AAS merupakan produk politik yang akan dipasarkan untuk memperoleh dukungan.

\section{KESIMPULAN DAN SARAN}

Hasil penelitian menunjukkan bahawa pemasaran politik Pull marketing ABM-Enny bersama timnya dalam kemenangan pada pemilihan gubernur Sulawesi Barat tahun 2017 cukup efektif. Hal itu tercapai karena kemampuan aktivitas pemasaran politik yang dilakukan, dengan menggunakan strategi pull marketing yang dikombinasikan dengan strategi pemsaran politik yang lainnya seperti startegi push marketing dan pass marketing. Yaitu pemanfaatan media sosial dalam mobilisasi massa sebelum melakukan kunjungan langsung kelapangan (pull marketing). Pemasaran politik yang dilakukan melalui media sosial juga dimanfaatkan dengan strategi menghadirkan para publik figur yang dianggap berpengaruh sehingga dapat pula mempengaruhi pilihan masyarakat (pass marketing).

\section{SARAN}

Pada era digital dengan perkembangannya yang sangat pesat, disarankan kepada para pelaku politik baik kontestan maupun penyelenggara untuk memanfaatkan media online sebagai sarana dalam mendukung demokrasi digital. Menyampaikan segala apapun yang berkaitan dengan pemilu melalui media sosial sebagai sebuah informasi yang layak dan dapat mendidik perilaku masyarakat dalam merespon pesta demokrasi. Para kontestan 
dapat menyalurkan kampanye politiknya melalui media sosial dengan menyedorkan berbagai visi dan misi atau tujuan dan target yang akan dicapai apabila terpilih nantinya. Sehingga calon pemilih betul-betul selektif dalam menjatuhkan pilihannya. Kepada penyelanggara pemilu (KPU) maupun pengawas pemilu (BAWASLU) juga dapat menggunakan media internet/media sosial dalam menyampaikan segala hal yang perlu untuk disampaikan kepublik. Sehingga dapat menciptakan pemilih yang cerdas dan selanjutnya menjadi pemilu yang berkualitas.

\section{DAFTAR RUJUKAN}

Agama, Y. (2015). Strategi PDI Perjuangan dalam Memenangkan Pasangan Jokowi-Jusuf Kalla Pada Pemilihan Presiden dan Wakil Presiden 2014. Jurna Politico, 2 (6).

Akmal \& salman. (2015). Partisipasi Politik Belia Secara 'Online' Melalui Ruang Demokrasi Maklumat Media Baru. Jurnal Komunikasi Malaysian Journal of Communication Jilid 31(1) 2015: 81-100

Alami, A. N. (2013). Menakar Kekuatan Media Sosial Menjelang Pemilu 2014. Jurnal Penelitian Politik Volume 10 No. 1 Juni 2013: 85-100

Ardha, B. (2014). Sosial Media Sebagai Media Kampanye Partai Politik 2014 Di Indonesia. Jurnal Visi Komunikasi Volume 13, No. 01, Mei 2014: 105-120

Firmanzah. (2018). Marketing Politik .Jakarta: Yayasan Pustaka Obor Indonesia.

Haroen, D. (2014). Personal Branding: Kunci Sukses Berkiprah Di Dunia Politik. Jakarta: PT Gramedia Pustaka Utama.

Moleong, L, J. (2007). Metodologi Penelitian Kualitatif (edisi revisi). Bandung: PT. Remaja Rosdakarya.

Morissan. (2014). Media Sosial Dan Partisipasi Sosial Di Kalangan Generasi Muda. Jurnal Visi Komunikasi Volume 13, No. 01, Mei 2014: 50-68

Nurfalah, F. \& Wihayati, W. (2013). Persepsi Khalayak Dalam Penggunaan Media Jejaring Sosial Untuk Kampanye Politik. Jurnal SIGNAL Vol 4, No 1 (2016)

Nursal, A. (2004). Political Marketing: Strategi Memenangkan Pemilu. Jakarta: Gramedia Pustaka Utama.

Pangeman, M. J. (2013). Pemasaran Politik Pada Pemilukada (Studi Pemasaran Politik Pasangan Hanny Sondakh dan Maximiliam Jonas Lomban, SE, M. Si Pda Pemilukada di Kota Bitung Tahun 2010),. Jurnal Politico, 1 (3).

Ratnamulyani, I. A. \& Maksudi, B. I. (2018). Peran Media Sosial Dalam Peningkatan Partisipasi Pemilih Pemula Dikalangan Pelajar Di Kabupaten Bogor. Jurnal Ilmu-ilmu Sosial dan Humaniora. Vol . 20, No. 2, Juli 2018: $154-161$

Riciani, A. A. (2016). Peran Komisi Pemilihan Umum Raya Melalui Media Sosial Dalam Upaya Meningkatkan Partisipasi Politik Mahasiswa Pada Pemilu Raya Prodi PPKN Unesa Periode 2016-2017. Kajian Moral dan Kewarganegaraan. Volume 03 Nomor 04 Tahun 2016, $1810-1824$

http://www.transtipo.com/news/agus-ambo-djiwa-pasanganabm-enny-unggul-70-persen-matra/

https://8enam.com/hadir-kampanye-abm-enny-aas-jadikanmambi-lautan-manusia/

http://makassar.tribunnews.com/2017/02/27/ini-hasil-akhirrekap-suara-pilgub-sulbar

http://news.rakyatku.com/read/39111/2017/02/18/inilah-hasilakhir-real-count-pilgub-sulbar-2017

https://www.antaranews.com/berita/434118/golkar-sulbarunggul-suara-demokrat-menang-kursi

http://news.rakyatku.com/read/32123/2016/12/20/jumlahdpt-pilgub-sulbar-840-091-ini-sebarannya 